OPEN ACCESS

Edited by:

Trish Fleming,

Murdoch University, Australia

Reviewed by:

Peter Banks,

University of Sydney, Australia

Narelle Dybing

Murdoch University, Australia

*Correspondence:

Kaylee A. Byers

kaylee.byers@ubc.ca

tThese authors have contributed equally to this work

Specialty section:

This article was submitted to

Urban Ecology,

a section of the journal

Frontiers in Ecology and Evolution

Received: 11 October 2018 Accepted: 22 February 2019

Published: 15 March 2019

Citation:

Byers KA, Lee MJ, Bidulka JJ, Patrick DM and Himsworth CG (2019) Rat in a Cage: Trappability of Urban Norway Rats (Rattus norvegicus).

Front. Ecol. Evol. 7:68.

doi: 10.3389/fevo.2019.00068

\section{Rat in a Cage: Trappability of Urban Norway Rats (Rattus norvegicus)}

\author{
Kaylee A. Byers ${ }^{1,2,3 *}$, Michael J. Lee ${ }^{2,4 \dagger}$, Julie J. Bidulka ${ }^{5}$, David M. Patrick ${ }^{4,6}$ and \\ Chelsea G. Himsworth ${ }^{2,4,5}$
}

${ }^{1}$ Department of Interdisciplinary Studies, University of British Columbia, Vancouver, BC, Canada, ${ }^{2}$ Canadian Wildlife Health Cooperative, Animal Health Centre, Abbotsford, BC, Canada, ${ }^{3}$ Biodiversity Research Centre, University of British Columbia, Vancouver, BC, Canada, ${ }^{4}$ School of Population and Public Health, University of British Columbia, Vancouver, BC, Canada, ${ }^{5}$ Animal Health Centre, British Columbia Ministry of Agriculture, Abbotsford, BC, Canada, ${ }^{6}$ British Columbia Centre for Disease Control, Vancouver, BC, Canada

Understanding the local ecology of urban Norway rats (Rattus norevgicus) is necessary to inform effective rat mitigation strategies. While Capture-Mark-Recapture (CMR) methods can be used to acquire such ecological information (e.g., abundance, movement patterns, and habitat use), these techniques assume that all individuals of the study population are equally trappable. To test whether urban rats adhere to this assumption, we conducted a 4-week CMR study in an urban neighborhood of Vancouver, Canada, to evaluate whether rat characteristics (i.e., age, sex, size, wound status, and infection with the pathogen Leptospira spp.) were associated with trappability. We found that the majority of rats entered traps in the first 2 weeks of trapping, and that larger rats were caught earlier in the trapping period. However, smaller, sexually immature rats were recaught more often than were larger, sexually mature rats, suggesting that prior capture affects the ability to recapture urban Norway rats. This highlights the need for CMR studies to account for size, sexual maturity, and prior capture when interpreting data.

Keywords: capture-mark-recapture method (CMR), ecology, Norway rat, Rattus, trappability, trapping bias, urban

\section{INTRODUCTION}

Norway rats (Rattus norvegicus) are infamous urban exploiters, thriving in cities worldwide (Feng and Himsworth, 2014). Consequences of infestations can be severe. First, they are economically costly, estimated to account for over 19 billion dollars in damages annually in the United States through their consumption and contamination of food products alone (Pimentel et al., 2000). At the regional level, an estimate by the province of Alberta, Canada projected that rats would cost up to 42.5 million dollars annually in the absence of their current rodent control program (McClay et al., 2004). Second, rats place considerable pressures on ecosystems, contributing to global biodiversity loss both directly (e.g., through predation) and indirectly (e.g., through habitat modification and species displacement) (Towns et al., 2006; Jones et al., 2008; Doherty et al., 2016). Third, rats pose a health risk to human populations, harboring numerous zoonotic pathogens (those transmissible between animals and people) responsible for human morbidity and mortality in cities globally (Himsworth et al., 2013b).

An understanding of urban rat ecology is the cornerstone of any attempt to understand rats and rat-associated issues. To gain this knowledge, ecological methods such as Capture-Mark-Recapture (CMR) can be used to estimate population characteristics like abundance and density 
(Wilson et al., 2007; Robinson et al., 2009; Sarmento et al., 2010), demographic characteristics (Votier et al., 2005; Lachish et al., 2007; Graham et al., 2013), and movement patterns (Beirinckx et al., 2006; Lagrange et al., 2014; Tuckey et al., 2017). However, traditional CMR techniques generally assume that all individuals are equally trappable over time (Krebs and Boonstra, 1984; Conroy and Carroll, 2009; Lindberg, 2012), an assumption which has not held in other species (e.g., Byrne et al., 2012; Carter et al., 2012; Camacho et al., 2017).

Although several models have been developed to address unequal detection of individuals within a population (reviewed by Gimenez et al., 2018), selecting and properly parameterizing an appropriate model is improved by information on trappability. Indeed, Abadi et al. (2013) stated that CMR models should incorporate animal characteristics that affect the probability of capture (e.g., sex, age) as covariates. When these covariates vary with time, termed "states" (e.g., reproductive status, or disease status), multi-state CMR models can be employed, which allow for individuals to transition among states (Gimenez et al., 2018). Further, where states relating to capture probability (i.e., trap aware or trap unaware) are affected by events (e.g., captured or not captured) multi-event models (an expansion of multi-state models; Pradel, 2005) can be used to more broadly reflect individual heterogeneity (Pradel and Sanz-Aguilar, 2012). Finally, when heterogeneity is not fully captured by covariates and states, individual heterogeneity can be modeled as individual random effects (Abadi et al., 2013). Therefore, it is important to understand the extent of capture heterogeneity within a population to first determine whether to incorporate it into CMR models (Ford et al., 2012), and second to identify an appropriate model and parameters.

The extent to which urban rats adhere to the assumption of equal trappability is largely unknown. Studies of their forestdwelling conspecifics suggest that trap-related factors such as bait type (Laurance, 1992), trap type (Blackwell et al., 2002), and odors from previous occupants (e.g., predators and conspecifics) (Tobin et al., 1995; Parsons et al., 2015) may influence which individuals enter traps (i.e., trappability). Beyond trap-related effects-which can be controlled for through thoughtful study design (Williams et al., 2002) - trappability may vary with rat characteristics. For example, two capture-removal studies found that larger, sexually mature rats were more likely to enter traps early in a trapping period (Davis and Emlen, 1956; Himsworth et al., 2014a), countering assumptions of equal trappability. If the assumptions of CMR are not met, then this may lead to significant errors in the interpretation of the resulting data. For example, given that Leptospira spp., a zoonotic bacterial pathogen shed in rat urine, is more prevalent among larger, sexually mature rats (Himsworth et al., 2013a; Minter et al., 2017), the tendency for larger, sexually mature rats to enter traps earlier than other members of the population may result in inflated prevalence estimates for Leptospira spp.

Trappability may also be impacted by prior capture. Marked individuals can become "trap shy", whereby individuals avoid traps they have been caught in previously (Evans, 1951; Tanaka,

Abbreviations: CMR, capture-mark-recapture.
1963; King et al., 2003; Linhart et al., 2012), or "trap-happy", resulting in numerous recapture events (Geis, 1955; Morris, 1955; Tanaka, 1963; Gurnell, 1982). Although both Norway and black rats (Rattus rattus) may display neophobic behavior (Barnett, 1963; Clapperton, 2006), to our knowledge there has been only one other study to date which assessed how prior capture influences the trappability of Norway rats, and this study was performed in a rural setting (Tanaka, 1963).

The overarching objective of this study was to test the assumption of equal trappability of urban Norway rats. Specifically, we evaluated whether rat characteristics (i.e., age, sex, size, wound status, and infection with the pathogen Leptospira spp.) and prior capture were associated with trappability. This information will be valuable for future studies aimed at understanding rat ecology and rat-related issues (e.g., rat control, rat-associated public health risks, etc.).

\section{METHODS}

\section{Trapping}

Trapping was carried out in an urban neighborhood in Vancouver, British Columbia, Canada. Rats were trapped from June 2016-January 2017 in 31 proximal city blocks (Figure 1) which were selected as part of a larger CMR study (e.g., Byers et al., 2017; Donovan et al., 2018; Lee et al., 2018). Briefly, ten Tomahawk Rigid Traps (Tomahawk Live Traps, Hazelhurst, USA) were deployed in each city block. These traps were placed inside stainless-steel trap covers to prevent vandalism (Integrated Pest Supplies Ltd, New Westminster, Canada) and were chained to immovable objects along the length of the alleyway that bisected each city-block. To acclimatize rats to traps, traps were pre-baited for one week and fixed in an open position (Barnett, 1963). Bait consisted of peanut butter mixed with oats, and Hydrogel (ClearH2O, Westbrook, USA) was provided as a water source. Where possible, traps were placed against vertical surfaces in the path of potential rat runways (Himsworth et al., 2014a).

Following pre-baiting, active trapping commenced and continued for 4 weeks. Traps were set each evening by 16:00 and checked each morning by 07:00. Traps were set 5 days a week, and fixed open and baited on the sixth and seventh day. Traps were disinfected using $10 \%$ bleach immediately following any period of prebaiting (i.e., prior to active capture) as well as following any time a rat was captured to prevent the potential effect of odor on rat trappability [bleach and other disinfectants have been shown not to impact the trappability of various species of small mammals (Van Horn and Douglass, 2000; Wilson and Mabry, 2010)] and the unintended transmission of pathogens among rats (Health Canada, 2011).

\section{Sampling}

Trapped rats were transported to the back of a mobile laboratoryvan, where each individually-caged animal was placed above a disinfected plastic tray and covered with a blanket to minimize stress. Urine was collected directly from the tray using a sterile syringe and was stored at $-80^{\circ} \mathrm{C}$ until it was tested for Leptospira spp. Subsequently, rats were transferred into an inhalation induction chamber (Kent Scientific, Torrington, USA) and 


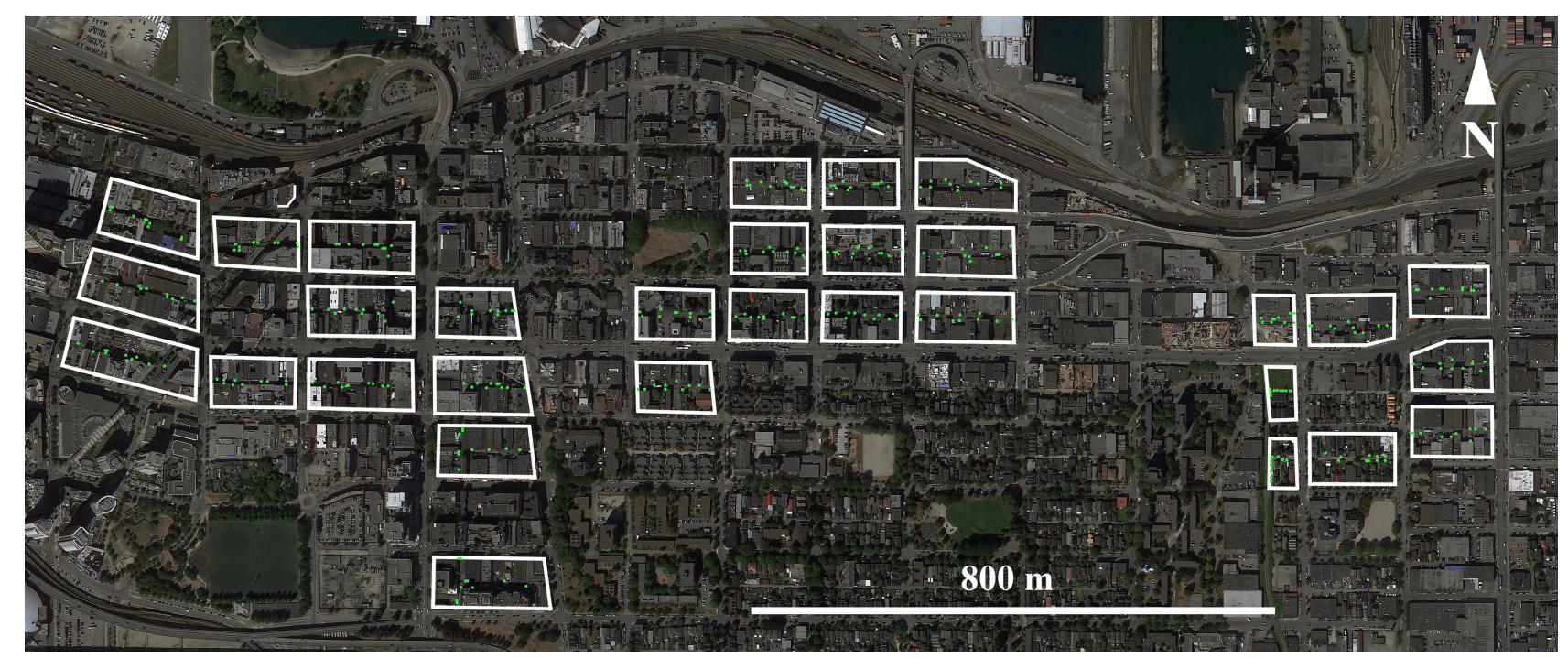

FIGURE 1 | Map of study sites in Vancouver, BC, Canada. Within each of the 31 city blocks where rats were trapped, green circles indicate the positions of the 10 traps placed in each block. Images provided through Google Earth Professional (https://www.google.com/earth/versions/\#download-pro).

anesthetized with 5\% isoflurane in oxygen using an isoflurane vaporizer (Associated Respiratory Veterinary Services, Lacombe, Canada). Anesthesia was maintained throughout sampling.

For each rat the following data were collected: body weight (grams), total length (nose-to-tip of tail in centimeters), sexual maturity (males with scrotal testes and females with a perforate vagina were considered mature), sex (male or female), and the presence/absence of bite wounds [presence determined as per (Himsworth et al., 2014b)]. Each rat was given a uniquely numbered laser-etched ear-tag (Kent Scientific, Torrington, USA) for identification upon recapture. Rats were allowed to recover fully from anesthesia (15-30 $\mathrm{min}$ ) before being released at the exact location of their capture.

Occasionally there were too many rats caught for the field team to process. In those cases, rats that had not been processed by $1,600 \mathrm{~h}$ were counted but released without collection of additional data or sampling. The order in which rats were sampled was randomized by city-block each day.

\section{Leptospira spp. Testing}

Starting urine volumes ranged between 20 and $200 \mu \mathrm{L}$ and all were volume corrected to $200 \mu \mathrm{L}$ using sterile, $1 \mathrm{X}$ Phosphate Buffer Solution buffer, pH 7.4. Nucleic acid extraction and amplification of the LipL32 gene [encodes an outer membrane lipoprotein virulence factor (Stoddard et al., 2009) of pathogenic Leptospira species] was performed as outlined previously in Lee et al. (2018). Samples were classified as negative (cycle threshold $[\mathrm{Ct}]) \geq 40$, suspect positive $(\mathrm{Ct}=37-39.99)$, or positive $(\mathrm{Ct}$ $\leq 36.99$ ). Any sample within the suspect range was retested three times.

\section{Statistics}

\section{Trap Success}

To determine trap success, we divided the total number of rats caught by the total trap effort and adjusted according to Nelson and Clark (1973). This method accounts for the capture of nontarget species and accidental trap activation by subtracting half a trapping unit from the total trap effort for each sprung trap.

\section{Trappability}

Linear regression was used to characterize the association between trap day (i.e., the day during the trapping period in which a rat was first captured, with "Day 1" being the first day of active trapping in any given city block) and the following covariates: sex, sexual maturity, weight, total length, bite wound presence, Leptospira spp. status, and season of capture (summer: June-August; and fall: September-November). Bivariable linear regression was used to individually examine the relationships between trap day and each characteristic and all covariates that were associated with trap day with a $p<0.10$ were carried forward into a multivariable model. A backwards selection process was used to select the multivariable model with the lowest Akaike Information Criterion (AIC) to balance and compare relative model fit and parsimony. As weight and length were collinear (Spearman's Rho $=0.93, p<10^{-15}$ ), they were considered in separate competing models. Model assumptions were assessed in both the bivariable comparisons and in the final multivariable model. Biologically plausible interactions were assessed in the final model (i.e., between: weight and bite wounds; weight and sexual maturity; weight and sex).

\section{Retrappability}

Logistic regression was used to characterize the association between the aforementioned covariates and whether a rat was recaptured (yes/no) within seven days of their initial capture. A seven-day recapture window was chosen to ensure that every rat had an equal opportunity to be recaptured regardless of whether it was caught at the beginning or at the end of the trapping period. Note that 114 of $147(78 \%)$ recaptured rats in the larger CMR study were recaught within seven days 
of initial capture. Bivariable and multivariable modeling was carried out as described above; however, weight and length were dichotomized around their medians because they were not linearly associated with the log odds of the outcome. Biologically plausible interactions were assessed in the final model (i.e., between: weight and bite wounds; weight and sexual maturity; weight and sex).

\section{Effect of the City-Block}

To assess whether there was clustering of explanatory variables associated with the outcome by city-block, we compared the final multivariable model to the same model while including a random effect for the city-block, for both the trappability model (mixed effects linear regression) and the retrappability model (mixed effects logistic regression).

All analyses were carried out using R Studio version 1.1.456 (Boston, USA). Regression was performed using the stats (R Core Team, 2018) and lme4 (Bates et al., 2015) packages.

\section{RESULTS}

Altogether, 580 individual Norway rats were captured over 20 trap days with an overall trap success of $14 \%$. Of the 580 Norway rats caught, $231(39.8 \%)$ were caught in week one, $137(23.6 \%)$ in week two, $106(18.3 \%)$ in week three, and 106 (18.3\%) in week four (Figure 2). Data were not collected for 195 rats (unmarked) because there were too many rats for the field team to process in one day. An additional six rats had missing data for one or more variables under consideration. A total of 379 rats were included in subsequent analyses.

\section{Trappability}

Among the 379 rats included for consideration, 195 (51\%) were male (106 mature, 89 immature) and 184 (49\%) were female (101 mature, 83 immature). The median weight and length of rats included in the trappability model were $111 \mathrm{~g}$ and $30.5 \mathrm{~cm}$ respectively. Urine was sampled from 335 individuals of which 39 (12\%) were positive for Leptospira spp. (Table 1).

Upon bivariable linear regression (Table 2), weight $(p<$ $0.01)$, length $(p<0.01)$, and wound presence $(p<0.001)$ were significantly $(p<0.05)$ associated with trap day. However, in the final multivariable model, only weight $\left(\right.$ beta $_{\text {adj }}=-0.0091,95 \%$ $\mathrm{CI}=(-0.015,-0.0036), p=0.00134)$ was retained, although length was roughly equivalent in that it explained approximately the same amount of variation in trap day $\left(\mathrm{R}_{\text {length }}^{2}=0.02626\right.$; $\mathrm{R}_{\text {weight }}^{2}=0.02696$ ) (Supplementary Figure 1). In this model, heavier rats were more likely to be caught earlier in the trapping period. No interactions that were assessed were statistically significant in the final model.

\section{Retrappability}

In the first three weeks of trapping, 281 rats were released. Twenty-three rats were not released because they died either prior to or following anesthesia. While the cause of death for these individuals is unknown, some of these rats showed signs of rodenticide poisoning (i.e., bleeding from nose and mouth), malnutrition, and significant wounding (i.e., large open wounds).
Indeed, rodenticide application was common in the study area and therefore it is highly probable that many of the captured rats had previously consumed rodenticides.

Seventy-three (26\%) rats were recaptured, and 55 (75\%) of these individuals were recaught within seven days of their initial capture. Of these, 46 were recaught once, seven were recaught twice (six immature and one mature rat), and two were recaught three times (both immature rats). Twenty-nine (53\%) recaptured rats were male (13 mature, 16 immature) and 26 (45\%) were female ( 9 mature, 17 immature) (Table 1). The median weight and length of rats included in the retrappability model were $80 \mathrm{~g}$ and $27 \mathrm{~cm}$, respectively. Four of the recaptured rats $(8 \%)$ tested positive for Leptospira spp. (Table 1).

Upon bivariable logistic regression (Table 3), the odds of being recaptured were significantly lower for rats that were mature $(p<0.01)$, that weighed $111 \mathrm{~g}$ or more $(p<0.001)$, and that were $30.5 \mathrm{~cm}$ or more in total length $(p<0.01)$. In the final multivariable model, only dichotomous weight was retained; however, while weight alone was the best predictor of whether a rat would be recaptured, the model containing length was roughly equivalent $\left(\mathrm{AIC}_{\text {weight }}=269.26, \mathrm{AIC}_{\text {length }}=271.34\right)$. In this final model, larger rats were significantly less likely to be recaptured with rats heavier than the median weight having 0.34 times the odds of being recaptured as compared to rats less than the median weight $(95 \% \mathrm{CI}=(0.18,0.62)$. No interactions that were assessed were statistically significant in the final model.

\section{Effect of the City-Block}

In the Trappability Model, adding the random effect of the block did not substantially change the effect of weight on trap day (beta $\left._{\text {adj }}=-0.009,95 \% \mathrm{CI}=(-0.15,-0.0031), p<0.01\right)$. However, the variance associated with the effect of the block was 2.14 and the relative fit of the model increased slightly $\left(\mathrm{AIC}_{\text {no random effect }}=2350.9, \mathrm{AIC}_{\text {random effect included }}=2344.6\right.$; Supplementary Figure 2). Similarly, in the Retrappability Model, adding the random effect of the block did not impact the effect of weight on recapture $\left(\mathrm{OR}_{\mathrm{adj}}=0.34,95 \% \mathrm{CI}=(0.18,0.62)\right.$, $p<0.001)$. Further, the variance associated with the effect of the block was 0 and the relative fit of the model decreased with the addition of the random effect $\left(\mathrm{AIC}_{\text {no random effect }}=269.26\right.$, $\mathrm{AIC}_{\text {random effect included }}=271.3$ ).

\section{DISCUSSION}

Understanding the characteristics that influence urban rat trappability is essential to inform the design and interpretation of capture-based programs seeking to describe local rat ecology. We found that the number of rats captured decreased over the trapping period and that larger rats were more likely to enter traps earlier in the trapping period and were less likely to be recaught than were smaller rats. Together, these results suggest that urban Norway rats do not follow the assumption of equal trappability, and that CMR studies may be biased toward obtaining more robust capture histories for smaller individuals than larger individuals. Therefore, studies modeling CMR data for rats should consider distinct probabilities of capture based 


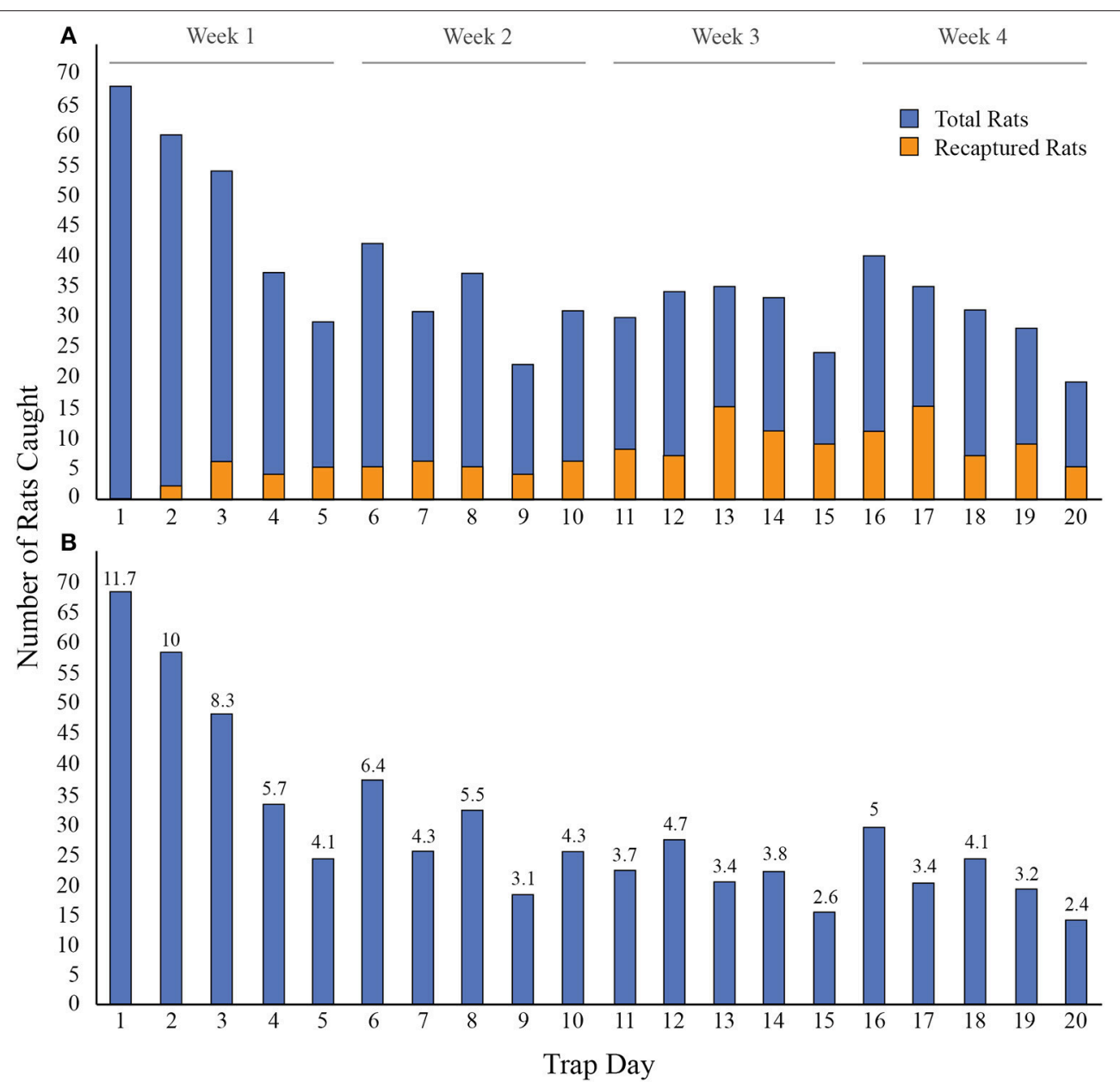

FIGURE 2 | Norway rats caught each day over 20 days in 31 city blocks of Vancouver, Canada. A. The number of rats caught each day, including rats caught only once (blue) and rats that were recaptured (orange), for a total of 720 rat capture events. B. The number of new rats caught each day (i.e. without recaptured rats). The percentage of rats caught out of the total number of individual rats $(n=580)$ is displayed on the top of each bar for each trap day (e.g., $11.7 \%$ of individuals were caught on day one).

on characteristics such as size and sexual maturity as well as differential impacts of prior capture on individual trappability.

\section{Trapping Period}

Trapping duration is an important component of CMR studies. Insufficient trapping periods may result in low sample sizes and thus affect accurate estimates of population characteristics (Olsen, 1975; Burke et al., 1995). However, extending trapping duration can be prohibitive due to equipment and labor costs. In this study, we found that trap success was greatest in the first week of trapping, with pronounced declines in rat numbers following the first day. These results are similar to a previous study which found that the greatest number of rats $(22.2 \%)$ were caught on the first day of a 12-day trapping period (Himsworth et al., 2014a). Decreasing numbers of trapped rats using CMR could suggest that the proportion of "trap shy" individuals increases over the trapping period (Tanaka, 1963). Our results suggest that trapping initiatives may benefit from maximizing their efforts in the first week of trapping and highlights the importance of understanding how certain methods could increase trap success in that period (e.g., pre-baiting).

\section{Trappability}

Larger rats were more likely to enter traps early in the trapping period (Supplementary Figure 1). These results align with previous trap-removal studies which found that larger, sexually mature rats were more likely to enter traps in the first few days of trapping than were smaller, sexually immature rats (Davis and Emlen, 1956; Himsworth et al., 2014a). This is important because it suggests that short-term trappingbased studies seeking to describe local rat population ecology may be biased toward oversampling larger individuals. This is particularly problematic for studies evaluating the disease ecology and population health risks associated with urban rats because a number of zoonotic pathogens are associated with rat size (Glass et al., 1988; Himsworth et al., 2013a, 2014c). It is interesting therefore, that our study found no 
TABLE 1 | Descriptive statistics of captured urban Norway rats (Rattus norvegicus).

\begin{tabular}{|c|c|c|c|c|}
\hline Covariate & Levels & $\begin{array}{c}\text { Not recaptured } \\
\text { Total rats }=324 \\
N \text { (\%total) }\end{array}$ & $\begin{array}{c}\text { Recaptured } \\
\text { Total rats }=55^{a} \\
N \text { (\%total) }\end{array}$ & $\begin{array}{c}\text { Overall sample } \\
\text { Total rats }=379 \\
N \text { (\%total) }\end{array}$ \\
\hline Sex & Male & $166(51)$ & $29(53)$ & $195(51)$ \\
\hline Sexual Maturity & Immature & $139(43)$ & $33(60)$ & $172(45)$ \\
\hline Dichotomous Weight & $>=111 \mathrm{~g}$ & $171(53)$ & $19(35)$ & $190(50)$ \\
\hline \multirow[t]{2}{*}{ Dichotomous Length } & $<30.5 \mathrm{~cm}$ & $151(47)$ & $35(64)$ & $186(49)$ \\
\hline & $>=30.5 \mathrm{~cm}$ & $173(53)$ & $20(36)$ & $193(51)$ \\
\hline \multirow[t]{2}{*}{ Wound Presence } & None & $250(77)$ & $43(78)$ & $293(77)$ \\
\hline & Present & $74(23)$ & $12(22)$ & $86(23)$ \\
\hline
\end{tabular}

a Only considered rats within the seven-week window for recapture $(n=281)$.

burine was not collected from all rats included in this analysis $\left(n_{\text {total }}=335, n_{\text {not recaptured }}=283, n_{\text {recaptured }}=52\right)$.

TABLE 2 | Unadjusted (bivariable) and adjusted (multivariable) linear regression of each rat characteristic against the outcome of trap day; $N=379$.

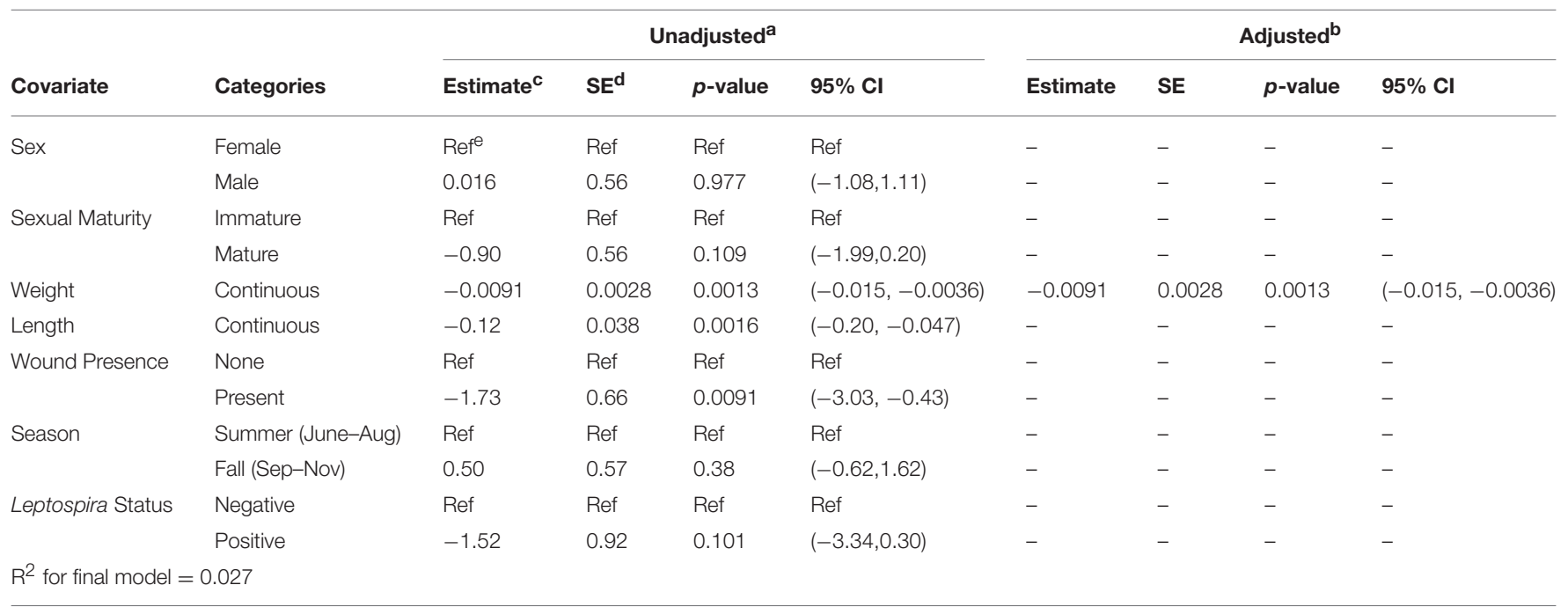

${ }^{a}$ Bivariable linear regression.

${ }^{b}$ Multivariable linear regression.

${ }^{c}$ Estimated effect of the given variable for a 1-day increase in trap day.

${ }^{d}$ Standard error.

${ }^{\text {e }}$ Reference category.

association between trappability and carriage of Leptospira spp., even without controlling for characteristics such as weight. This suggests that carriage of Leptospira spp. may not be associated with the probability of capture. Finally, trappability was affected by some unmeasured block-level characteristic (e.g., resource availability). While our analysis was concerned with assessing the characteristics of individuals that entered traps earlier vs. later in a trapping period, it could also be that block-level characteristics influence the tendency of rats to enter traps.

\section{Retrappability}

While the number of new rats captured decreased with time, the number of recaptured individuals increased in the latter half of the trapping period. This is unsurprising, as the number of marked individuals available for recapture increases with the number of individuals marked. In this study, smaller rats were more likely to be recaught than larger rats. This is important because it suggests that prior capture may differentially affect trappability. Differences in aversion between smaller and larger rats may be due to differential access to resources (Feng and 
TABLE 3 | Unadjusted (bivariable) and adjusted (multivariable) logistic regression of each rat characteristic against the outcome of binary recapture (yes/no).

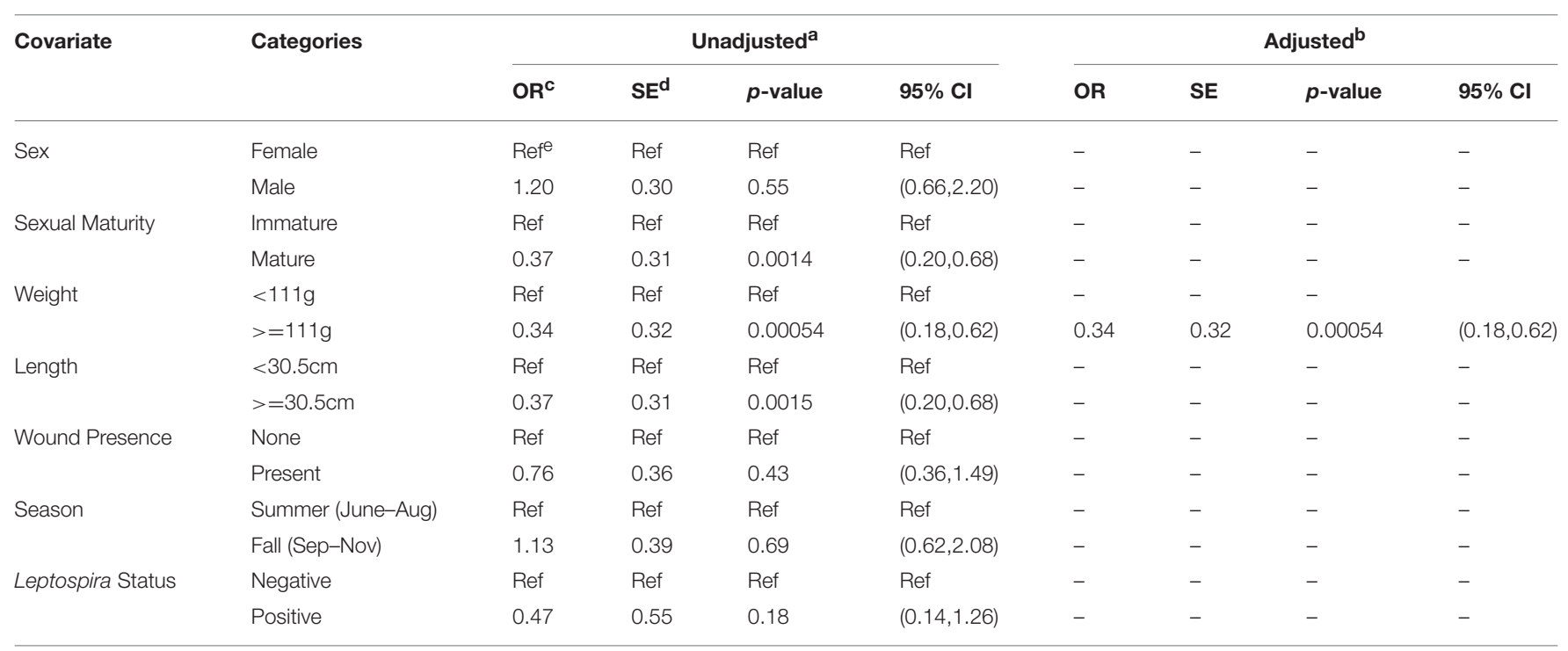

The seven-day recapture window includes rats caught for the first time in the first three weeks of trapping; $N=281$.

${ }^{a}$ Bivariable logistic regression.

${ }^{b}$ Multivariable logistic regression.

${ }^{c}$ Odds ratio.

${ }^{d}$ Standard error.

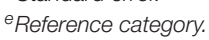

Himsworth, 2014) whereby smaller, less dominant individuals are relegated to resources associated with increased risk (e.g., bait in traps). Indeed, experimental studies have demonstrated that adolescent rats (up to 60 days of age) display greater risktaking behaviors than adults (Imhof et al., 1993). In addition to size, sexual maturity was associated with odds of recapture in the bivariable but not the multivariable model, suggesting that size likely represents more than just sexual maturity and that smaller, mature rats also have a decreased odds of recapture. This could be due to the relationship between an individual's body mass and their position within the social hierarchy of their colony, or as a general indicator of malnourishment, both of which could influence the results of CMR studies. Unlike with trappability, there did not appear to be an influence of blocklevel characteristics on retrappability. This may be due in part to dominance characteristics of rats which dictate rat interactions (Barnett, 1958). Dominance interactions may influence the tendency for subordinate rats to re-enter traps regardless of block-level characteristics. Finally, while there was no association between Leptospira spp. and retrappability, it is difficult to draw definitive conclusions given its overall low prevalence combined with the limited sample size for the recapture analysis.

\section{Limitations}

One potential limitation of the retrappability model is the restriction of designating rats as "recaught" only if they were recaught within seven days of their initial capture. This sevenday window was used in order to allow all rats an equal time to reenter traps. Although an initial assessment of the larger CMR dataset indicated that the majority of individuals were recaught within seven days, it could be that this timeframe biased our sample of recaught rats. For example, it is possible that larger rats require more time to overcome acquired trap shyness, and thus may be more likely to re-enter traps after seven days of capture. However, an analysis of the rats caught outside of the seven-day window demonstrated that these rats were on average $138 \mathrm{~g}(\mathrm{n}=16)$, within the weight range assigned to "smaller rats". Additionally, while our study found that $12 \%$ of rats were positive for Leptospira spp., it is possible that this is an underestimate of the actual number of infected rats as previous studies in in other species found intermittent or decreasing shedding of Leptospira over time (Leonard et al., 1992; Rocha et al., 2017). However, in a study which evaluated Leptospira shedding by Norway rats over two months in Salvador, Brazil, the bacteria was shed consistently over time (Costa et al., 2015), and therefore the extent to which variations in shedding affects our study is unclear. Finally, as there may be many rats in an area which never enter traps, it is important to note that our study can only make inferences on the "trappable" population of Norway rats, and may not be reflective of the entire population.

\section{CONCLUSIONS}

Overall, our study demonstrates that: (1) trap success is greatest at the start of a trapping period; (2) larger rats are more likely to enter traps early in the trapping period compared to smaller rats; and (3) smaller rats are more likely to reenter traps than larger rats. This is important because it indicates that urban Norway rats violate the assumption of equal trappability inherent to traditional CMR methods. We suggest that studies employing these methods consider rat characteristics as well as the impact of capture during study design, CMR model selection, and data interpretation. 


\section{DATA AVAILABILITY}

Datasets are available upon request. The data supporting the conclusions of this manuscript will be made available by the authors, without undue reservation, to any qualified researcher.

\section{ETHICS STATEMENT}

All procedures and protocols for this study were approved by the University of British Columbia's Animal Care Committee (A140265) and are in accordance with the Canadian Council on Animal Care's national guidelines.

\section{AUTHOR CONTRIBUTIONS}

This study was conceived of by $\mathrm{KB}, \mathrm{ML}$, and $\mathrm{CH}$. Sample collection and data analysis was performed by KB, ML, and JB. Writing of the initial draft of the manuscript was performed by $\mathrm{KB}$ and $\mathrm{ML}$ with substantial contributions from $\mathrm{CH}$. All authors contributed to revising the manuscript. Funding was acquired by $\mathrm{KB}$ and DP.

\section{REFERENCES}

Abadi, F., Botha, A., and Altwegg, R. (2013). Revisiting the effect of capture heterogeneity on survival estimates in capture-mark-recapture studies: does it matter? PLOS ONE 8:e62636. doi: 10.1371/journal.pone.006 2636

Barnett, S. A. (1958). An analysis of social behaviour in wild rats. Proc. Zool. Soc. Lond. 130, 107-152. doi: 10.1111/j.1096-3642.1958.tb00565.x

Barnett, S. A. (1963). The rat: A study in behaviour. Chicago, IL: Aldine Publishing Co

Bates, D., Maechler, M., Bolker, B., and Walker, S. (2015). Fitting linear mixedeffects models using lme4. J. Stat. Softw. 67, 1-48. doi: 10.18637/jss.v0 $67 . \mathrm{i} 01$

Beirinckx, K., Van Gossum, H., Lajeunesse, M. J., and Forbes, M. R. (2006). Sex biases in dispersal and philopatry: insights from a meta-analysis based on capture-mark-recapture studies of damselflies. Oikos 113, 539-547. doi: 10.1111/j.2006.0030-1299.14391.x

Blackwell, G. L., Potter, M. A., and McLennan, J. A. (2002). Rodent density indices from tracking tunnels, snap-traps and fenn traps: do they tell the same story? N. Z. J. Ecol. 26, 43-51.

Burke, V. J., Greene, J. L., and Whitfield Gibbons, J. (1995). The effect of sample size and study duration on metapopulation estimates for slider turtles (Trachemys scripta). Herpetologica 51, 451-456. doi: 10.2307/38 92770

Byers, K. A., Lee, M. J., Donovan, C. M., Patrick, D. M., and Himsworth, C. G. (2017). A novel method for affixing Global Positioning System (GPS) tags to urban Norway rats (Rattus norvegicus): feasibility, health impacts and potential for tracking movement. J. Urban Ecol. 3:e68496. doi: 10.1093/jue/jux010

Byrne, A. W., O'Keeffe, J., Green, S., Sleeman, D. P., Corner, L. A. L., Gormley, E., et al. (2012). Population estimation and trappability of the European badger (Meles meles): implications for tuberculosis management. PLoS ONE 7:e50807. doi: 10.1371/journal.pone.005 0807

Camacho, C., Canal, D., and Potti, J. (2017). Lifelong effects of trapping experience lead to age-biased sampling: lessons from a wild bird population. Anim. Behav. 130, 133-139. doi: 10.1016/j.anbehav.2017.06.018

Carter, A. J., Heinsohn, R., Goldizen, A. W., and Biro, P. A. (2012). Boldness, trappability and sampling bias in wild lizards. Anim. Behav. 83, 1051-1058. doi: 10.1016/j.anbehav.2012.01.033

\section{FUNDING}

This study was supported by the University of British Columbia's (UBC) Public Scholars Initiative (KB) and Canada's Natural Sciences and Engineering Research Council (NSERC; grant number: 2015-05058) (DP).

\section{ACKNOWLEDGMENTS}

We would like to thank Drs. Michael Whitlock, Charles Krebs, and Bobby Corrigan for their input in the design of this project, as well as Christina Donovan, Sophia Kontou, and Geoffroy Knaub for their assistance with field work. We also thank the Vancouver Area Network of Drug Users and the Structural Pest Management Association of British Columbia for their support of our project.

\section{SUPPLEMENTARY MATERIAL}

The Supplementary Material for this article can be found online at: https://www.frontiersin.org/articles/10.3389/fevo. 2019.00068/full\#supplementary-material

Clapperton, B. K. (2006). A review of the current knowledge of rodent behaviour in relation to control devices. Sci. Conserv. 263, 1-55.

Conroy, M. J., and Carroll, J. P. (2009). "Capture-mark-recapture studies for estimating abundance and density," in Quantitative Conservation of Vertebrates (Oxford: Wiley-Blackwell), 135-159.

Costa, F. E., Wunder, E. A. Jr., De Oliveira, D., Bisht, V., Rodrigues, G., Reis, M. G., et al. (2015). Patterns in Leptospira shedding in Norway rats (Rattus norvegicus) from Brazilian slum communities at high risk of disease transmission. PLoS Negl. Trop. Dis. 9:e0003819. doi: 10.1371/journal.pntd.00 03819

Davis, D. E., and Emlen, J. T. (1956). Differential trapability of rats according to size and sex. J. Wildl. Manag. 20, 326-327. doi: 10.2307/379 6975

Doherty, T. S., Glen, A. S., Nimmo, D. G., Ritchie, E. G., and Dickman, C. R. (2016). Invasive predators and global biodiversity loss. Proc. Natl. Acad. Sci. U.S.A. 113, 11261-11265. doi: 10.1073/pnas.160248 0113

Donovan, C. M., Lee, M. J., Byers, K. A., Bidulka, J., Patrick, D. M., and Himsworth, C. G. (2018). Leptospira spp. in the oral cavity of urban brown rats (Rattus norvegicus) from vancouver, Canada-implications for rat-rat and rat-human transmission. J. Wildl. Dis. 54, 635-637. doi: 10.7589/2017-0 8-194

Evans, F. C. (1951). Notes on a population of the striped ground squirrel (Citellus tridecemlineatus) in an abandoned field in southeastern Michigan. J. Mammal. 32, 437-449. doi: 10.2307/1375792

Feng, A. Y. T., and Himsworth, C. G. (2014). The secret life of the city rat: a review of the ecology of urban Norway and black rats (Rattus norvegicus and Rattus rattus). Urban Ecosyst. 17, 149-162. doi: 10.1007/s11252-013-03 05-4

Ford, J. H., Bravington, M. B., and Robbins, J. (2012). Incorporating individual variability into mark-recapture models. Meth. Ecol. Evol. 3, 1047-1054. doi: 10.1111/j.2041-210X.2012.00243.x

Geis, A. D. (1955). Trap response of the cottontail rabbit and its effect on censusing. J. Wildl. Manag. 19, 466-472. doi: 10.2307/3797457

Gimenez, O., Cam, E., and Gaillard, J.-M. (2018). Individual heterogeneity and capture-recapture models: what, why and how? Oikos 127, 664-686. doi: 10.1111/oik.04532

Glass, G. E., Childs, J. E., Korch, G. W., and Leduc, J. W. (1988). Association of intraspecific wounding with hantaviral infection in wild rats (Rattus 
norvegicus). Epidemiol. Infect. 101, 459-472. doi: 10.1017/S09502688000 54418

Graham, J., Smith, G. C., Delahay, R. J., Bailey, T., McDonald, R. A., and Hodgson, D. (2013). Multi-state modelling reveals sexdependent transmission, progression and severity of tuberculosis in wild badgers. Epidemiol. Infect. 141, 1429-1436. doi: 10.1017/S09502688120 03019

Gurnell, J. (1982). Trap response in woodland rodents. Acta Theriol. 27, 123-137. doi: 10.4098/AT.arch.82-10

Health Canada (2011). Pathogen Safety Data Sheets: Infectious Substances Leptospira Interrogans. Available online at: https://www.canada.ca/en/publichealth/services/laboratory-biosafety-biosecurity/pathogen-safety-datasheets-risk-assessment/leptospira-interrogans-material-safety-data-sheetsmsds.html

Himsworth, C. G., Bidulka, J., Parsons, K. L., Feng, A. Y. T., Tang, P., Jardine, C. M., et al. (2013a). Ecology of Leptospira interrogans in Norway rats (Rattus norvegicus) in an inner-city neighborhood of vancouver, Canada. PLoS Negl. Trop. Dis. 7:e2270. doi: 10.1371/journal.pntd.00 02270

Himsworth, C. G., Jardine, C. M., Parsons, K. L., Feng, A. Y. T., and Patrick, D. M. (2014a). The characteristics of wild rat (Rattus spp.) populations from an inner-city neighborhood with a focus on factors critical to the understanding of rat-associated zoonoses. PLoS ONE 9:e91654. doi: 10.1371/journal.pone.009 1654

Himsworth, C. G., Parsons, K. L., Jardine, C., and Patrick, D. M. (2013b). Rats, cities, people, and pathogens: a systematic review and narrative synthesis of literature regarding the ecology of rat-associated zoonoses in urban centers. Vector Borne Zoonotic Dis. 13, 349-359. doi: 10.1089/vbz.2012. 1195

Himsworth, C. G., Patrick, D. M., Mak, S., Jardine, C. M., Tang, P., and Weese, J. S. (2014c). Carriage of Clostridium difficile by wild urban Norway rats (Rattus norvegicus) and black rats (Rattus rattus). Appl. Environ. Microbiol. 80, 1299-1305. doi: 10.1128/AEM.03609-13

Himsworth, C. G., Zabek, E., Tang, P., Parsons, K. L., Koehn, M., Jardine, C. M., et al. (2014b). Bacteria isolated from conspecific bite wounds in Norway and black rats: implications for rat bite-associated infections in people. Vector Borne Zoonotic Dis. 14, 94-100. doi: 10.1089/vbz.2013. 1417

Imhof, J. T., Coelho, Z. M. I., Schmitt, M. L., Morato, G. S., and Carobrez, A. P. (1993). Influence of gender and age on performance of rats in the elevated plus maze apparatus. Behav. Brain Res. 56, 177-180. doi: 10.1016/0166-4328(93)90036-P

Jones, H. P., Tershy, B. R., Zavelta, E. S., Croll, D. A., Keitt, B. S., Finkelstein, M. E., et al. (2008). Severity of the effects of invasive rats on seabirds: a global review. Conserv. Biol. 22, 16-26. doi: 10.1111/j.1523-1739.2007.00 859.x

King, C. M., Davis, S. A., Purdey, D., and Lawrence, B. (2003). Capture probability and heterogeneity of trap response in stoats (Mustela erminea). Wildl. Res. 30, 611-619. doi: 10.1071/WR02091

Krebs, C. J., and Boonstra, R. (1984). Trappability estimates for mark-recapture data. Can. J. Zool. 62, 2440-2444. doi: 10.1139/z84-360

Lachish, S., Jones, M., and McCallum, H. (2007). The impact of disease on the survival and population growth rate of the Tasmanian devil. J. Anim. Ecol. 76, 926-936. doi: 10.1111/j.1365-2656.2007.01272.x

Lagrange, P., Pradel, R., Bélisle, M., and Gimenez, O. (2014). Estimating dispersal among numerous sites using capture-recapture data. Ecology 95, 2316-2323. doi: $10.1890 / 13-1564.1$

Laurance, W. F. (1992). Abundance estimates of small mammals in Australian tropical rainforest: a comparison of four trapping methods. Wildl. Res. 19, 651-655. doi: 10.1071/WR9920651

Lee, M. J., Byers, K. A., Donovan, C. M., Bidulka, J. J., Stephen, C., Patrick, D. M., et al. (2018). Effects of culling on Leptospira interrogans carriage by rats. Emerging Infect. Dis. 24, 356-360. doi: 10.3201/eid2402.171371

Leonard, F. C., Quinn, P. J., Ellis, W. A., and O'Farrell, K. (1992). Duration of urinary excretion of leptospires by cattle naturally or experimentally infected with Leptospira interrogans serovar hadjo. Vet. Rec. 131, 435-439. doi: $10.1136 /$ vr.131.19.435
Lindberg, M. S. (2012). A review of designs for capture-mark-recapture studies in discrete time. J. Ornithol. 152, S355-S370. doi: 10.1007/s10336-010-05 33-9

Linhart, P., Fuchs, R., Polákov,á, S., and Slabbekoorn, H. (2012). Once bitten twice shy: long-term behavioural changes caused by trapping experience in willow warblers Phylloscopus trochilus. J. Avian. Biol. 43, 186-192. doi: 10.1111/j.1600-048X.2012.05580.x

McClay, A. S., Fry, K. M., Korpela, E. J., Lange, R. M., Roy, L. D., and Alberta Research Council (2004). "Costs and threats of invasive species to Alberta's natural resources," in Alberta Sustainable Resource Development, (Edmonton, AB), 1-122.

Minter, A., Diggle, P. J., Costa, F., Childs, J., Ko, A. I., and Begon, M. (2017). Evidence of multiple intraspecific transmission routes for Leptospira acquisition in Norway rats (Rattus norvegicus). Epidemiol. Infect. 70, 1-11. doi: 10.1017/S0950268817002539

Morris, R. F. (1955). Population studies on some small forest mammals in eastern Canada. J. Mammal. 36, 21-35. doi: 10.2307/1375718

Nelson, L., and Clark, F. W. (1973). Correction for sprung traps in catch/effort calculations of trapping results. J. Mammal. 54, 295-298. doi: 10.2307/1378903

Olsen, R. W. (1975). Length of trapping period in population studies. J. Mammal. 56, 696-697. doi: 10.2307/1379487

Parsons, M. H., Sarno, R. J., and Deutsch, M. A. (2015). Jump-starting urban rat research: conspecific pheromones recruit wild rats into a behavioral and pathogen-monitoring assay. Front. Ecol. Evol. 3:146. doi: $10.3389 /$ fevo.2015.00146

Pimentel, D., Lach, L., Zuniga, R., and Morrison, D. (2000). Environmental and economic costs of nonindigenous species in the United States. Bioscience 50, 53-65. doi: 10.1641/0006-3568(2000)050[0053:EAECON]2.3.CO;2

Pradel, R. (2005). Multievent: an extension of multistate capturerecapture models to uncertain states. Biometrics 61, 442-447. doi: 10.1111/j.1541-0420.2005.00318.x

Pradel, R., and Sanz-Aguilar, A. (2012). Modelling trap-awareness and related phenomena in capture-recapture studies. PLoS ONE 7:e32666. doi: 10.1371/journal.pone.0032666

R Core Team (2018). R: A Language and Environment for Statistical Computing. Vienna: R Foundation for Statistical Computing. Available online at: https:// www.R-project.org/.

Robinson, S. J., Waits, L. P., and Martin, I. D. (2009). Estimating abundance of American black bears using DNA-based capture-mark-recapture models. Ursus 20, 1-11. doi: 10.2192/08GR022R.1

Rocha, B. R., Narduche, L., Oliveira, C. S., Martins, G., and Lilenbaum, W. (2017). Molecular demonstration of intermittent shedding of Leptospira in cattle and sheep and its implications on control. Cienc. Rural 46:e2017088. doi: 10.1590/0103-8478cr20170088.

Sarmento, P. B., Cruz, J. P., Eira, C. I., and Fonseca, C. (2010). Habitat selection and abundance of common genets Genetta genetta using camera capture-markrecapture data. Eur. J. Wildl. Res. 56, 59-66. doi: 10.1007/s10344-009-0294-Z

Stoddard, R. A., Gee, J. E., Wilkins, P. P., McCaustland, K., and Hoffmaster, A. R. (2009). Detection of pathogenic Leptospira spp. through TaqMan polymerase chain reaction targeting the LipL32 gene. Diagn. Microbiol. Infect. Dis. 64, 247-255. doi: 10.1016/j.diagmicrobio.2009.03.014

Tanaka, R. (1963). On the problem of trap-response types of small mammal populations. Res. Popul. Ecol. 5, 139-146. doi: 10.1007/BF0251 8838

Tobin, M. E., Engeman, R. M., and Sugihara, R. T. (1995). Effects of mongoose odors on rat capture success. J. Chem. Ecol. 21, 635-639. doi: 10.1007/BF02033706

Towns, D. R., Atkinson, I. A. E., and Daugherty, C. H. (2006). Have the harmful effects of introduced rats on islands been exaggerated? Biol. Invasions 8, 863-891. doi: 10.1007/s10530-005-0421-z

Tuckey, T. D., Fabrizio, M. C., Norris, A. J., and Groves, M. (2017). Low apparent survival and heterogeneous movement patterns of invasive blue catfish in a coastal river. Mar. Coast. Fish. 9, 564-572. doi: 10.1080/19425120.2017.13 81207

Van Horn, R. C., and Douglass, R. J. (2000). Disinfectant effects on capture rates of deer mice (Peromyscus maniculatus). Am. Midl. Nat. 143, 257-260. doi: 10. 1674/0003-0031(2000)143[0257:DEOCRO]2.0.CO;2 
Votier, S. C., Hatchwell, B. J., Beckerman, A., McCleery, R. H., Hunter, F. M., Pellatt, J., et al. (2005). Oil pollution and climate have widescale impacts on seabird demographics. Ecol. Lett. 8, 1157-1164. doi: 10.1111/j.1461-0248.2005.00818.x

Williams, B. K., Nichols, J. D., and Conroy, M. J. (2002). Analysis and Management of Animal Populations: Modeling, Estimation, and Decision Making. San Diego, CA: Academic Press.

Wilson, D. J., Efford, M. G., Brown, S. J., Williamson, J. F., and McElrea, G. J. (2007). Estimating density of ship rats in New Zealand forests by capture-markrecapture trapping. N. Z. J. Zool. 31, 47-59. doi: 10.2307/24058126

Wilson, J. A., and Mabry, K. E. (2010). Trapping mammals in a cautious world: the effect of disinfectants on trap success. West. N. Am. Nat. 70, 467-473. doi: 10.3398/064.070.0406
Conflict of Interest Statement: The authors declare that the research was conducted in the absence of any commercial or financial relationships that could be construed as a potential conflict of interest.

The reviewer, ND, and handling Editor declared their shared affiliation.

Copyright $\odot 2019$ Byers, Lee, Bidulka, Patrick and Himsworth. This is an open-access article distributed under the terms of the Creative Commons Attribution License (CC $B Y)$. The use, distribution or reproduction in other forums is permitted, provided the original author(s) and the copyright owner(s) are credited and that the original publication in this journal is cited, in accordance with accepted academic practice. No use, distribution or reproduction is permitted which does not comply with these terms. 